UNITED STATES DEPARTMENT OF THE INTERIOR

Harold L. Ickes, Secretary

GEOLOGICAL SURVEY

W. C. Mendenhall, Director

\title{
Bulletin 931-F
}

\section{NICKEL DEPOSITS}

\section{OF BOHEMIA BASIN AND VICINITY YAKOBI ISLAND, ALASKA}

\author{
BY \\ JOHN C. REED AND JOHN VAN N. DORR 2D
}

Strategic Minerals Investigations, 1941

(Pages 105-138)

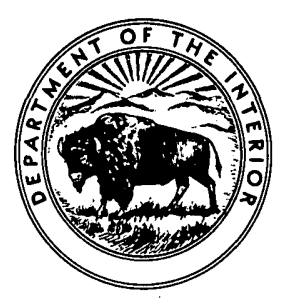

UNITED STATES

GOVERNMENT PRINTING OFFICE'

WASHINGTON : 1942

For ale by the Superintendent of Documents, Washington, D. C. - - - . - - • - Price 70 cents 

Abstract ..................................

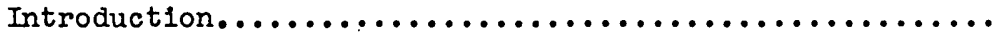

Gөography.................................

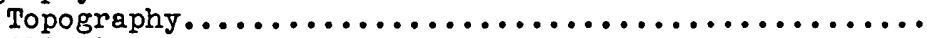

Climate...............................

Geology...................................

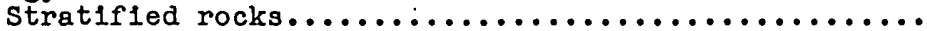

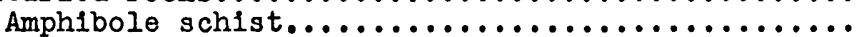

Amphibole-epidote schist...................

Graywacke.............................

Intrusive rocks...........................

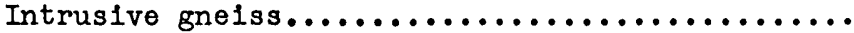
Amphibolite.........................

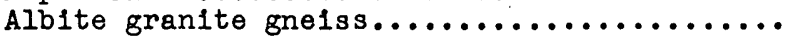

The diorite group........................ Nortte.............................

Gabbro.............................

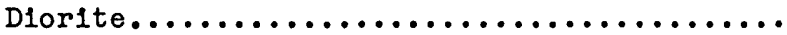

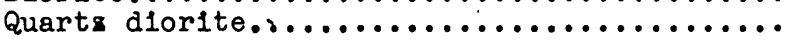

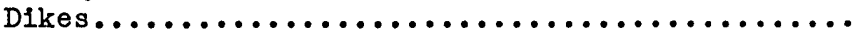

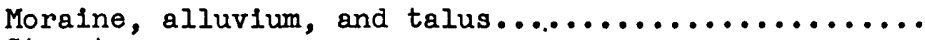

Structure...............................

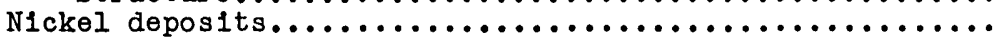

History.................................

Mineralogy and paragenesis...................

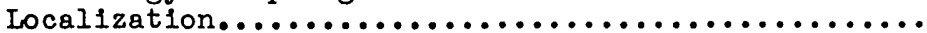

N1ckel-bearing bodies......................... North Muskeg body.........................

South Muskeg body........................

side Hill body............................

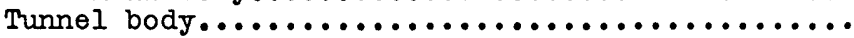

Trlpod bodles...........................

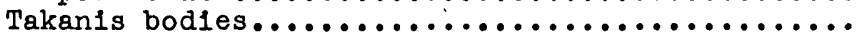

Unprospected bodies.......................

Tonnage and grade of sulfide-bearing bodies..........

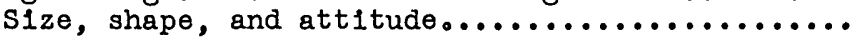

Grade..................................

Samples...............................

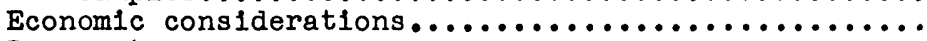

Prospects................................ 


\section{ILLUSTRATIONS}

Plate 20. Geologic and topographic map of Bohemia Basin and vicinity, Yakob1 Island, Alaska..... In pocket 21. Geologic and topographic map of the area surrounding the Tripod, Tunnel, Side Hill, and Muskeg sulfide-bearing bodies, Yakob1

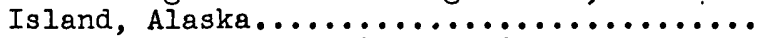

22. Geologic and topographic map of the area surrounding the Takanis sulfide-bearing bodles, Yakobi Island, Alaska.............. 124

23. Geologic maps of prospect pits and tunnel in sulfide-bearing bodies of Bohemia Basin and vicinity, Yakob1 Island, Alaska........ In pocket

Figure 10. Index map showing location of Bohemia Basin, Yakob1 Island, Alaska................ 108 


\title{
NICKEL DEPOSITS OF BOHEMIA BASIN AND VICINITY,
}

\author{
YAKOBI ISLAND, ALASKA
}

By John C. Reed and John Van N. Dorr 2d

\section{ABSTRACT}

The nickel deposits of Bohemia Basin and vicinity are on Yakob1 Island, about 130 miles by water west of Juneau. The district is readily accessible by boat or alrplane.

The oldest rocks of the vicinity consist of a thick sequence of strata that is thought to be in part of Upper Triassic and in part of Lower Cretaceous age. The Trlassic (?) rocks are largeif volcanic with some sedimentary material, whereas the Cretaceous (?) rocks are largely graywacke. Within the district, these rocks have been metamorphosed to various kinds of schist.

The stratified rocks were invaded, probably in Cretaceous time, by gneissic rocks which are thought to be related to the Coast Range batholith of the mainland farther east. These intrusive rocks are principally gnelssic albite granite and amphibolite.

Along the west coast of Chichagof Island and on Yakob1 Island are several stocks of unfollated intrusive rocks of unknown age which are younger than the intrusive rocks mentioned above. These stocks consist of norite, gabbro, diorite, quartz diorite, granite, and albite granite.

The nickel deposits of Yakob1 Island are sulfide-bearing bodies containing pyrrhotite, pentlandite, and chalcopyrite, and are confined to the more calcic rocks, principally norite, of the younger intrusive stocks. They are belleved to be segregations of material that crystallized early from the magma from which all the rocks of the stock eventually consolidated.

Individual sulfide-bearing bodies reach a maximum of several hundred feet in length. Elght of these bodies have been partly opened by 19 prospect trenches and a tunnel. At least four additional known bodies have not yet been prospected and there probably are others not yet discovered.

The eight prospected sulfide-bearing bodies are estimated to contain about $6,000,000$ tons of rock that contains about 0.36 percent of nickel and 0.27 percent of copper. The estimate of tonnage is based on the assumption that each of the bodies extends to a depth below 1ts lowest outcrop equal to one-half of 1ts length. Further prospecting will probably show that the tonnage is much greater than this, but it probably will not greatiy change the estimate of the grade. Rough calculations indicate that, under economic conditions similar to those existIng in the early part of 1941, the deposits are marginal, especially since there is now no smelter on the Pacific Coast equipped to handle nickel ores. 


\section{INTRODUCTION}

Nlckel-bearing deposits are known to occur at several localIties on Yakob1 Island and the western part of Chichagof and Baranof Islands, the northernmost of the outer 1slands of the Alexander Archipelago of southeastern Alaska. The western parts of these 1slands have in most places received little geological study and have been incompletely prospected. They may well contain other bodies of rock similar to those which are known to carry nickel. According to present knowledge, the deposits center principally in three areas: Bonemia Basin on Yakobi Island, Mirror Harbor on Chlchagof Island, and Snlpe Bay on Baranof Island. This report deals only with the deposits of the most northerly area, in and near Bohemia Basin.

The authors' field work was done between the middle of May and the first of september 1940, under an allotment of funds made to the Survey for the investigation of strategic minerals. The authors were assisted by J. E. Mundine, recorder, and Darwin I. Rossman, rodman.

The United States Forest Service helped the Survey party in many ways, particularly by making available a launch for transporting the men and equipment to Yakob1 Island from Juneau and by furnishing a smaller launch to the party for about a month while the boat regularly chartered from the Public Roads Administration was undergoing repalrs. Acknowledgment is due Carl Vevelstad, who was in charge of the assessment work on the deposits while the Survey party was there, for permission to use a privately owned cabin for extended periods and for other favors. The writers are also indebted to P. S. Smith, H. G. Ferguson, and F. C. Calkins, of the Geological Survey, for helpful advice and criticism during the preparation of this report. 
The geology of the west coast of Chichagof Island has been described by Overbeck. I/ He devoted considerable study to the nickel deposits at Mirror Harbor, but those on Yakob1 Island had not been discovered at the time of his investigation. Buddington $2 /$ has discussed the Bohemia Basin deposits, and Buddington and Chapin $3 /$ mention them in their general report on the ore deposits of southeastern Alaska.

\section{GEOGRAPHY}

Yakob1 Island, about $18 \mathrm{miles}$ long, lies off the northwest corner of Chichagof Island and south of the entrance to Cross Sound (f1g. 10). Bohemia Basin, the local name for the open valley of Bohemia Creek, is on the east side of the 1sland about halfway between 1ts most northerly and 1ts most southerly points (pl. 20). The nearest settlement is Pelican, which has a post office and general store. It is about 7 miles east of Bohemia Basin, on the northeast side of Lisianski strait.

There is at present no regular means of transportation to Bohemia Basin. It can be reached, however, by small boat from Juneau, 130 miles to the east, or from sitka, about 80 miles southeast. An air transportation company which maintains frequent service to nearby points on Chichagof Island will land planes, if requested, on Llslanski stralt at the mouth of Bohemia Creok.

\section{Topography}

The district represented by plate 20 is rugged and ranges in altitude from sea level along Lislanski stralt to 2,472 feet at a peak on the northwest edge of the area. The district includes

1/ Orerbeck, R. U., Goology and mineral resources of the west coast of Ohlchagof Island: U. S. Cool. Survey Bull. 692, pp. 91-136, 1919.

2) Buddington, A. T., Mineral Investigations in southeastern Alaska: U. S. Gool. Survey Bull. 773, pp. 95, 98-105, 1925.

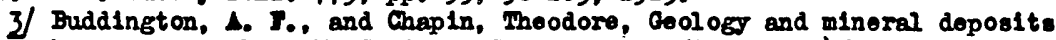
of southeastern Llasicas 0 . S. Gool. Surrog ball. 800, pp. 348-351, 1929. 


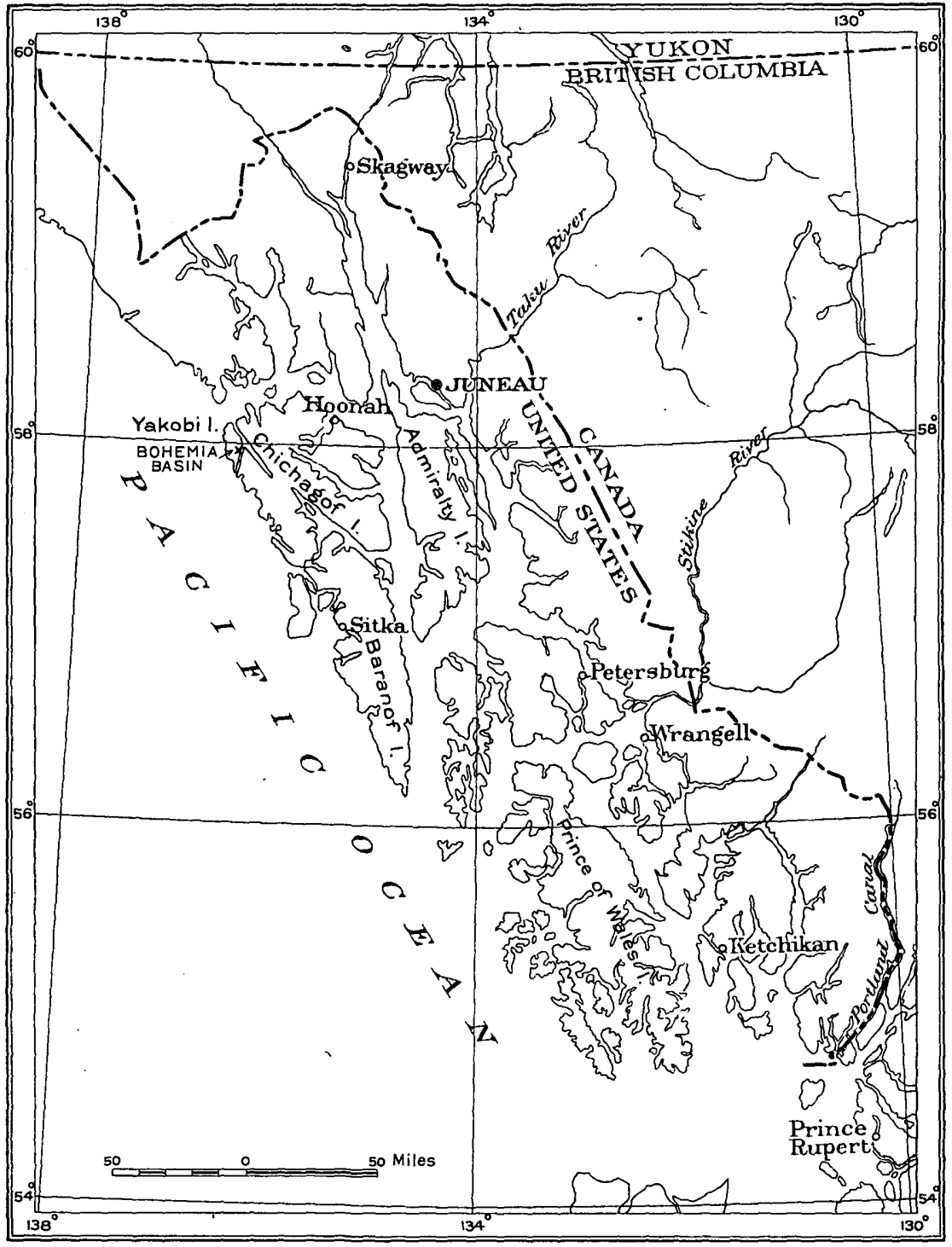

PIgure 10.--Index map showing location of Bohemla Basin, Yakobi Island, Alaska. 
the northeastern part of a deep trench which transects Yakob1 Island from Ilsianski stralt $\mathrm{S} .35^{\circ} \mathrm{W}$. to tidewater on the seaward side of the 1sland. The trench, or "through valley", is bounded on both sides by steep slopes rising to altitudes of over 2,000 feet. The drainage divide in the trench is only 518 feet above sea level. The northwest wall of the trench is stralghter, steeper, and less dissected by side valleys than the southeast wall. Although some of the bordering ridges are sharp, large areas on these ridges are rounded and rolling. Longltudinal ridge profiles are relatively gentle over long distances but are broken by a few sharp peaks that project above the general upland level.

\section{Climate}

The climate of Yakob1 Island is similar to that of Sitka, where a long record of observations indicates a mean annual preclpitation of about 86 inches, most of which falls as rain. 4 / June is commonly the driest month and october the wettest. Less than one inch of precipitation in any month is uncommon. January, with a mean temperature of about $32^{\circ}$, is the coldest month and July or August, with a mean temperature of about $55^{\circ}$, the warmest. The mean annual temperature is near $44^{\circ}$.

\section{GEOLOGY}

The oldest rocks of Yakob1 Island and adjacent parts of Chlchagof Island consist of a thick sequence of strata thought to be in part Upper Triassic and in part Lower Cretaceous. The Triassic (?) rocks are largely volcanic with some intercalated sediments, whereas the Cretaceous (?) rocks are mainly graywacke.

4) Climatological data, Alaska section: U. S. Dept. Agr., \#eather Bar., rol. 23, No. 13. 1937; v01. 24, №. 13, 1938.

428672 O - 42 - 2 
The stratifled rocks were invaded, probably in Cretaceous time, by rocks belleved to be related to the Coast Range batholith of the mainland farther east. These older intrusive rocks. In and near Bohemia Basin are largely gneissic and are principally albite granite and amphibolite.

On Yakob1 Island and along the west coast of Chichagof Island are several stocks of unfollated intmusive rocks. The age of the stocks is not known but they are younger than the gne1ss1c rocks. The stocks are composed of norite, gabbro, diorite, and quartz diorite; their average composition is perhaps about that of diorite.

\section{Stratified rocks}

Stratified rocks crop out over a little less than a third of the area represented by plate 20. They are most widespread in the southwest part of the area mapped. The stratifled rocks comprise three map units: Amphibole schist, amphibole-epidote schist, and graywacke.

The stratifled rocks of the area mapped have all been metamorphosed. Orlginally they consisted largely of such rocks as volcanic tuffs, brecclas, and lava flows, argillaceous and arenaceous sediments containing widely differing proportions of admixed pyroclastic material, and graywacke. They were extensiveIy folded and sheared during the mountain-building movements which accompanied the intrusion of the gne1ss, and were further metamorphosed by that intrusion. Later the stratified rocks were locally further metamorphosed by the intrusion of the dioritic stock.

Amphibole schist

- Amphibole schist is exposed in an almost continuous belt around that part of the stock which crops out near the center of 
the mapped area. Many of the inclusions in the stock consist of intensely metamorphosed amphibole schist.

The amphibole schist is commonly greenish gray, ranging from greenlsh black to light greenish gray. Locally it is very pyritic. The rock ranges in texture from schistose through platy to massive. It is ail so fine-grained that individual minerals can be distingulshed by the naked eye in only a few places. The rock is composed largely of a tight felt of tiny amphibole needles, probably actinolite or tremolite. The amphibole schist probably was formed by dynamic metamorphism of deposits that were mainly of pyroclastic origin, but in general the metamorphism has progressed so far that the character of the original rocks is obscured. Sandy, clayey, and limy materlal may have constltuted minor parts of the deposits in some places and some of the schist may have been formed by the metamorphism of lava flows.

The intrusion of the stock of unfollated rocks was accompanied by the metamorphism of the amphibole schist to amphibolite for a distance of several hundred feet from the contact. Inclusions of amphibole schist in the stock have been even more intensely metamorphosed than the rock of the amphibolite zone around the stock and are now composed of hornfels.

$$
\text { Amphibole-epidote schist. }
$$

The amphibole-epidote schist occupies an area south of the amphibole schist and southeast of Takanis Creek (pl. 20). Some. of the amphibole schist northwest of Takanis Creek probably is thermally metamorphosed amphibole-epidote schist. In general the amphibole-epidote schist is lighter-colored than the older amphibole schist and has a distinct green color. Most of the rock is distinctly schistose, but some is platy or massive. Like the amphibole schist, this formation probably originated by the metamorphism of material that was largely pyroclastic. 


\section{Graywacke}

The graywacke, which crops out in the southern part of the mapped area east of Takanis Lake and south of the amphibole-ep1dote schist, is part of the graywacke formation, probably of early Cretaceous age, that has been described in the Chichagof district. $5 /$

The rock is generally gray and locally is banded. It has been thermally metamorphosed by the intrusion of the dioritic stock to quartz-biotite schist, but enough of the original texture remains to indicate the poorly sorted nature of the original sediments. It consists mainly of quartz but sontains some plagioclase, biotite, and amphibole.

\section{Intrusive rocks}

Intrusive gneiss

Cretaceous (?) intrusive rocks, collectively called intrusive gneiss, crop out in the eastern and northeastern part of the area mapped and underlie a little more than a third of the area. These rocks were divided for mapping into two units, amphibolite and albite granite gneiss, though in many places the contact between them is gradational.

Most of the intrusive gneiss is well-follated and so greatly altered that its original composition is doubtful. It apparentIy was intensely metamorphosed during emplacement.

Amphibolite.--The amphibolite is made up principally of - coarse- and fine-grained amphibolite, with hornblende-quartz diorite as a minor component.

The fine-grained amphibolite ranges in color from dark gray to black. The principal minerals are amphibole and plagioclase but some of the rock is so fine-grained that the mineral components cannot be distinguished by the naked eye. 
The coarse-grained amphibolite, many crystals of which are more than an inch across, generally lacks the distinct follation of the fine-grained type. More than half of the typlcal rock is pale amphibole; the remainder, probably occupjing spaces originally filled with feldspar, is a mass of clinozolsite, epidote, and chlorite.

Albite granite gneiss.--The albite granite gneiss is also a collective unit which includes diorite, albite diorite, silic1fled albite granite, and clinozolsite gnelss, in addition to the predominant rock.

The albite granite gneiss is commonly light to medium gray, and is composed principally of quartz and albite in roughly equal amounts. This rock appears to have been formed by widespread albitization of gnelssic intrusive rock which was originally much more calcic.

\section{The diorite group}

Since all of the nickel deposits are in the rocks of this group, they will be described in greater detall than the other rocks in the area. Reconnaissance work has shown that the rocks of the diorite group, which crop out in two separated areas in the district mapped, are actualiy parts of a single large stock. The rocks have been divided into four map units: Norite, gabbro, diorite, and quartz diorite. These rocks grade into each other, so that the contacts between them were located more or less arbitrarliy at many places. The boundaries as located in the fleld do not coincide exactly with the various petrologic types later determined microscopically -- for example, the norite as mapped includes some gabbro, the gabbro some diorite, and the diorite some quartz diorite.

The distribution of the various components of the stock within the area represented on plate 20 is complex and appears to be more or less haphazard. In general, the norite, the only 
member of the group that carries significant amounts of nickel, forms irregular bodies enclosed within masses of more sodic rock. These norite bodies have a wide range in size. In that part of the stock exposed near the center of the mapped area the Inner portion consists largely of norite, and quartz diorite predominates near the borders. It is possible that the abundant quartz diorite in the southwest part of the mapped area may be only the border zone of more calclc interior parts of the stock outside the area mapped. Large bodies of norite are known to be present outside this area.

In the following descriptions, the various rocks of the diorite group will be described in order from those high in iron and calcium to those high in silica and sodium.

Norite.--The rocks of the norite unit range in color from dark gray, through dark waxy brown, to black, and their texture ranges from fine- to very coarse-grained. In the fleld, feldspars, amphiboles or pyroxenes, and sulfides are readily recognizable in much of the rock. In the sulfide-rich varieties, chalcopyrite can be identifled, but the other two common sulfides, pyrrhotite and pentlandite, cannot be distinguished from each other. Some of the norite weathers to lighter shades than the fresh rock, but the sulfide-bearing parts are commonly stained by hydrated oxides of iron.

The rocks mapped as norite include peridotite, amphibolite, basic pegmatite, and gabbro, as well as norite. The first three are minor members of the unit, and norite is by far the most abundant.

The typical feldspar of the norite is calcic labradorite, but in some specimens the feldspar is sodic bytownite and, in a very few, calcic andesine. The amount of feldspar ranges from about 20 to about 70 percent of the rock. The principal mafic minerals are orthorhombic pyroxene, monoclinic pyroxene, palebrown amphibole, and very pale green amphibole, in varying rela- 
tive amounts. Olivine is present in the norite in a few places. Interstitial sulfide minerals, including pyrrhotite, pentlandite, and chalcopyrite, are present almost everywhere but they are rarely abundant. Where they are abundant, they occur in irregular blebs as much as half an inch across and averaging possibly an eighth of an inch. The chief alteration product, other than amphibole after pyroxene, is chlorite.

The gabbro of the norite map unit is not very widespread and Is apparently identical with the more calcic part of the gabbro map unit.

Basic pegmatite is a minor but widespread constituent of the norite. It occurs in the noritic rocks ordinarily as irregular masses with gradational borders as well as in the form of tabular bodies with relatively sharp walls. Mineralogically this basic pegmatite closely resembles gabbro but it commonly is more feldspathic and contains a little quartz. It is extremely coarse-grained. Although basic pegmatite grades in many cases into sulfide-rich norite, it rarely contains sulfides.

Gabbro.--The gabbro map unit includes gabbro and diorite, both prevailingly medium-grained and gray.

The typical feldspar of the gabbro part of this unit is labradorite, though locally the feldspar is as calcic as sodic bytownite or as sodic as andesine. At most places feldspar forms between 50 and 60 percent of the rock, and the remainder consists largely of pale green and pale brown amphibole. Most thin sections show a few remnants of almost colorless monoclinic pyroxene surrounded by amphibole, which indicate that the amphibole is partly or entirely an alteration product from earlier pyroxene.

In the diorite of the gabbro map unit, andesine is the most common feldspar and he most abundant mafic minerals are pale green and pale brown amphiboles formed from original pyroxene. 
Diorite.--Diorite is shown separately on plate 20 only in the southwest part of the area mapped, where for the most part It occupies a border zone against the eastern contact of that part of the stock.

This diorite was distinguished in the field from the diorite included in the gabbro unit by its generally finer grain and darker color and by the presence of recognizable blotite, but microscopic study shows that mineralogically the two do not differ greatly. In general, the former contains a little less plagloclase and a little more of the mafic minerals. Blotite is apparently present everywhere, at least as an accessory, and may form as much as 20 percent of the rock. The other mafic minerals include the common pale-green and pale-brown amphiboles as well as a few pyroxene remnants.

A diagnostic feature of the diorite is the presence at many places of numerous partly digested inclusions of rock which are now hornfels but which apparently were originally graywacke. Locally these are so closely spaced that the diorite between them constitutes only a small proportion of the rock.

Quartz diorite.--The quartz diorite is generally light gray, unfollated, and coarse- to medium-grained. Some of it is porphyrit1c. The most abundant feldspar is andesine, but some thin sections contain considerable oligoclase and a few contain labradorite. The feldspar makes up about 40 to 65 percent of the rock, and the quartz content ranges from about 15 to 35 percent. The most abundant mafic mineral is pale amphibole, but biotite In most places constitutes as much as 10 percent of the rock.

\section{Dikes}

The rocks of Bohemia Basin and vicinity are cut by many dikes which vary widely in texture and mineral composition. Andesite dikes are by far the most abundant. Most of the dikes In the intrusive gneiss are altered and sheared, whereas those 
In the diorite group are fresh and unbroken. Some of the dikes in the stratified rocks appear to be related to the intrusive gnelss and some to the rocks of the stock.

\section{Moraine, alluvium, and talus}

Unconsolidated deposits of Plelstocene and Recent age overlie much of the bedrock in Bohemia Basin. Glacial deposits cover large parts of the valley floors. They are in general poorly drained and more or less covered with muskeg, which complicates transportation problems.

Alluvium occurs in patches along the major streams and at places along minor streams where they flatten abmuptly in prof1le.

Talus is widespread along the steep slopes bordering the through valley and in some of the cirques.

\section{$\underline{\text { structure }}$}

The structural trend in the area is to the northwest. The follation of the intrusive gnelss and the follation and bedding of the stratified rocks are dominantiy in this direction but abrupt local divergences from the general pattern are common. Dips are generally steep and may be elther to the northeast or southwest.

Since the rocks of the diorite group are diagnostically unfollated and since their outcrop pattern shows no evidence of any structural trend, it is evident that they must have been intruded after the relaxation of diastrophic pressures which imposed a structural pattern on the other rocks.

There are many small faults, in part older and in part younger than the intrusives of the diorite group, but these have no relation to the nickel deposits of the area.

428672 O - 42 - 3 


\section{NICKEL DEPOSITS}

\section{History}

Sulf1de-bearling bodies on Yakob1 Island were discovered in 1921 by S. H. P. Vevelstad. The first claims were staked in that jear and since then claims have been added covering both sldes of the valley of Bohemia Creek and the west shore of Lis1ansk1 Strait, from a little south of Bohemia Creek northeast to Miner Island, at the junction of Lislanski Stralt and Lislansk1 Inlet. This report does not describe the number, ownership, and locations of the many claims and groups of claims for these have changed several times. In 1939, the bodies hereinafter called the North Muskeg, South Muskeg, Side H1Il, Tunnel, East Tripod, and West Tripod were included in the Yakob1, formerly the Bohemia, group of claims. The bodies herelnafter called the North Takanis and South Takanis are belleved to have been included in the Mayflower and Portia groups of clalms. The exact number of claims in the district is not known but probably is more than a hundred.

In the summer of 1940 much of the area was restaked by an established mining company, but, according to reports, these claims were not recorded. The authors understand that some controversies have arisen as to titles and options on some of the claims.

Soon after the discovery of the sulfide-bearing deposits, a tunnel was started in the Tunnel body, and 1t has been lengthened from time to time until in 1940 it was 166 feet long. The sulfide bodies have also been opened by 15 prospect trenches ranging in length from 30 to 150 feet. Other trenches have been opened in rock with no significant concentration of sulfides or containing only non-nickeliferous pyrite. No ore has been shipped from the district. 


\section{Mineralogy and paragenesis}

The only metallic minerals present in appreciable quantities In the sulfide-bearing bodies are pyrrhotite, pentlandite, chalcopyrite, and magnetite. The nlckel is in the pentlandite.

Buddington $6 /$ reports small amounts of bravolte (?), ((Fe,N1) $\left.\mathrm{S}_{2}\right)$, and marcasite in highly altered material above the tunnel and from a mass of sulfides near the North Takan1s body and states that these minerals are secondary after pentlandite and pyrrhotite.

Calculations from chemical analyses of 61 samples aggregating about 650 pounds show that the sulfide-bearing bodies contain about 4.6 percent by welght of sulfide minerals, of which about 48 percent is pyrrhotite, 35 percent pentlandite, and 17 percent chalcopyrite. The total amount of sulfides and the relative abundance of each mineral range widely and irregularly within the bodies, but the average figures stated above are believed to be reliable for the district as a whole. The pyrrhotite-chalcopyrite ratio appears to vary more widely than the pyrrhotite-pentlandite ratio.

In some specimens the pyrrhotite appears to be the earliest sulfide, for it is cut by veinlets of pentlandite and chalcopyrite. In other specimens small blebs of pentlandite are enclosed in pyrrhotite, and C. F. Park, Jr., who kindly studied polished sections for the authors, suggests that these blebs may be remnants of early-formed, partly replaced pentlandite. These

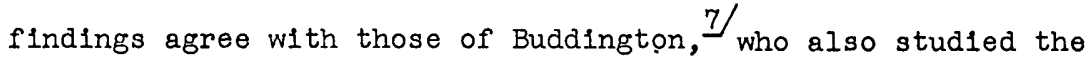
disseminated ores. Buddington also states that pentlandite collected only half an inch from weathered surfaces shows no traces of altieration.

\footnotetext{
6) Buddingt on, A. P., Mineral Invest1gations in southeastern Alaska:

U. S. Gool. Surves Bull. 773, pp. 103-105, 1925.

I) Buddington, A. F.. op. c1t., pp. 103-104, 1925.
} 
Magnetite forms veinlets and stringers in the gangue and occasionaliy in the pyrrhotite.

- The ore minerals were concentrated by the process of magmat1c segregation, and were among the last minerals to crystalize from that part of the cooling magma which formed the norite. The localization of the ore minerals in the most calcic unit of the differentiation series, the lack of any relationship between the distribution of ore minerals and structural features or dikes, the absence of any signs of hydrothermal activity in the host rock, and the general absence of sulfides in the basic pegmatite that grades into sulfide-rich norite, all point to concentration by segregation within the cooling magma.

\section{Localization}

It should be emphasized that although the nickel-bearing bodies are restricted to the noritic parts of a stock of generally dioritic composition, most of the norite does not contain significant concentrations of nickel.

Many of the nickel-bearing bodies within the norite masses Ile close to contacts between the norite and adjacent rocks and tend to be elongate parallel to those contacts (pls. 21 and 22).

The sulfide-bearing bodies grade locally through zones as much as 30 feet wide into barren enclosing rocks and hence the boundaries of these bodies as mapped are somewhat approximate. Many of the sulfide-bearing bodies inside the gradational zone appear richer near their outer borders. In some of the bodies, inclusions of hornfels are bordered by a zone relatively rich in sulfides. Because the rocks in many of the critical areas are concealed by unconsolidated material, these generalizations should be. tested further before they are widely applied.

The sulfide content differs greatly at different places within the sulfide-bearing bodies, and with the exceptions noted above, appears to be distributed erratically. Relatively rich 
material commonly passes abruptly into lean material without apparent change in host rock or local structure.

Most of the norite contains small quentities of sulfide minerals and many outcrops are deep brown owing to the weathering of these minerals to hydrated oxides of iron. The brown and dark-gray colors contrast sharply with the gray of the more sodic rocks. These rusty and somber colors help in 1dentifying the norite and the sulphide-bearing parts of it but do not necessarily indicate ore bodies. Although not1ceable gossans develop locally over outcrops of the sulfide-bearing bodies, some outcrops rich in sulfides are marked by only a little limonite.

Several areas of limonite-stained rocks 110 outside the areas of nickel-bearling norite. The stain is caused by the weathering of rock, in most places the amphibolite member of the gne1ss, that has been impregnated, apparently along fault zones, by pyrite and silica. A qualitative analysis of some of this pyritic material revealed no nickel.

\section{Nickel-bearing bodies}

Elght nickel-bearing bodles have been opened by prospect trenches and a single tunnel. Float and outcrops indicate the presence of at least four bodies as yet unprospected. The elght that have been prospected are nomed and discussed in some detall below; the unprospected bodies are discussed less fully. Plates 21 and 22 show the location and geologic relations of the var1ous named bodies.

\section{North Muskeg body}

The North Muskeg body, considered to be about 190 feet long, is opened by two p1ts, Nos. 2 and 3, having an aggregate length of about 150 feet. Because of the extensive cover of moraine and talus, little information could be obtained as to size, shape, and relation of this body to others. The sulfide-bearing 
body is limited on the north and east by outcrops of barren rock near and in P1t 2, but there is no evidence for several hundred. feet from the pits as to its possible extension to the west. About half way between PIts 3 and 5, two outcrops of barren norite seeril to limit the sulfide-bearing body in that direction. The average nickel content of the samples taken from this body 1s 0.39 percent.

\section{South Muskeg body}

The South Muskeg body, assumed to be 320 feet long, is opened by P1ts 4,5, and 7, which have an aggregate length of 187 feet. Here, as in the vicinit $\vec{J}$ of the North Muskeg body, the cover of moraine and talus is so extensive as to make the size and shape of the body uncertain. The hornfels exposed in P1t 4 , in conjunction with other nearby outcrops, definitely limits any extension of the sulfide-bearing body to the east and northeast. Hornfels also crops out about 50 feet southeast of Pit 5, thus limiting the body in that direction. The outcrops between Pits 3 and 5 limit the body to the northwest at 1 ts north end.

Although the rock exposed over a large area at the north end of Pit 5 is of low nickel content, it is considered to be part of a large sulfide-bearing-body opened by P1ts 4, 5, and 7, because sulfide-bearing outcrops are found between P1ts 4 and 5 and $\operatorname{close}$ to P1t 5. Pit 5 was extended about 20 feet to the southwest after the completion of the mapping in that area, and rock with a relatively high sulfide content was found. The samples indicate that the average nickel content of the body is

0.23 percent.

\section{S1de H1ll body}

The Side Hill body, assumed to be about 200 feet long, has $\checkmark$ been opened by P1ts 12 and 19, with an aggregate length in the 
body of 58 feet. Talus, stream gravel, vegetation, and soll cover the area so completely that, outside of the pits, only one outcrop of sulfide-bearing rock was found in the Immediate v1cinity.

This body is IImited about 100 feet southwest of P1t 12 by outcrops of hornfels and about 75 feet to the north by an outcrop of barren nor1te. The south end of P1t 19 is probably in the same body as P1t 12, but most of the former pit is in materlal so low in nickel and sulfides that the body was not considered to extend farther north than the southernmost 25 feet of that pit. The total length of sample cut in this body is 36 feet; the average grade is 0.26 percent of nickel and 0.21 per cent of copper.

It seems possible, though hardly probable, that the North Muskeg, South Muskeg, and Side Hill bodies, all of which lie within 600 feet of each other, are parts of one much larger body. No direct evidence, however, can be brought to bear on this question except the two small outcrops of barren norite between Pits 3 and 5, for the critical areas are covered by unconsolidated material.

Tunnel body

The Tunnel body, which has a maximum length of 460 feet, has been prospected only by a tunnel 166 feet long, 113 feet of which is in the body 1tself. For the most part the body is well-exposed on the surface, although the west end and the south side are partly covered by soll and vegetation. About 300 feet S. $35^{\circ} \mathrm{W}$. of the tunnel portal are several small outcrops of sulfide-bearing rocks surrounded by barren material, which may represent offshoots of the Tunnel body or which may be. very small individual bodies. The average nickel content of the samples taken from this body in the tunnel was 0.52 percent, but this probably is not entirely representative, because the ends 
of the body were not sampled and they appear to be of somewhat lower grade.

The tunnel which opens this body enters it 53 feet from the portal, but the outcrop of the body, 30 feet above the tunnel, is only 25, feet horizontally from the portal, which indicates a southerly dip, for the north side of the body. The first 15 feet of the tunnel penetrates sulfide-bearing rock which appears to be part of a small body not connected at the tunnel level with the main body. Part of the face of the tunnel is in sulfiderich rock and is 45 feet south of the southern limit of the body at the outcrop about 100 feet above the tunnel level. This also Indicates a southerly dip for the south side of the body.

\section{Tripod bodies}

The East and the West Tripod bodies have been opened by four pits, Nos. 8, 9, 10, and 11, with an aggregate length of 364 feet. The East Tripod body, 160 feet long, is opened by Pit 11, which has a total length in the body of 50 feet; the other pits are in the West Tripod body, which is about 400 feet long.

The West Tripod body is cut by many andesite dikes, but in the East Tripod body dikes are rare. The boundaries of both bodies are well-exposed except on their southeast sides, where talus hides much of the contact between sulfide-bearing and barren norite. Small outcrops in the talus below the pits define the eastern limits of the bodies fairly closely.

Small local faults, marked by some crushing and the development of fibrous amphiboles, are a minor feature of these bodies. The two bodies may be connected at depth or may even be connected on the surface by a narrow neck beneath the talus. In any case, the rocks between Pits 9 and 11 , exclusive of the barren norite exposed between the two bodies, seem to be of somewhat lower grade than those exposed in the pits. Samples of 

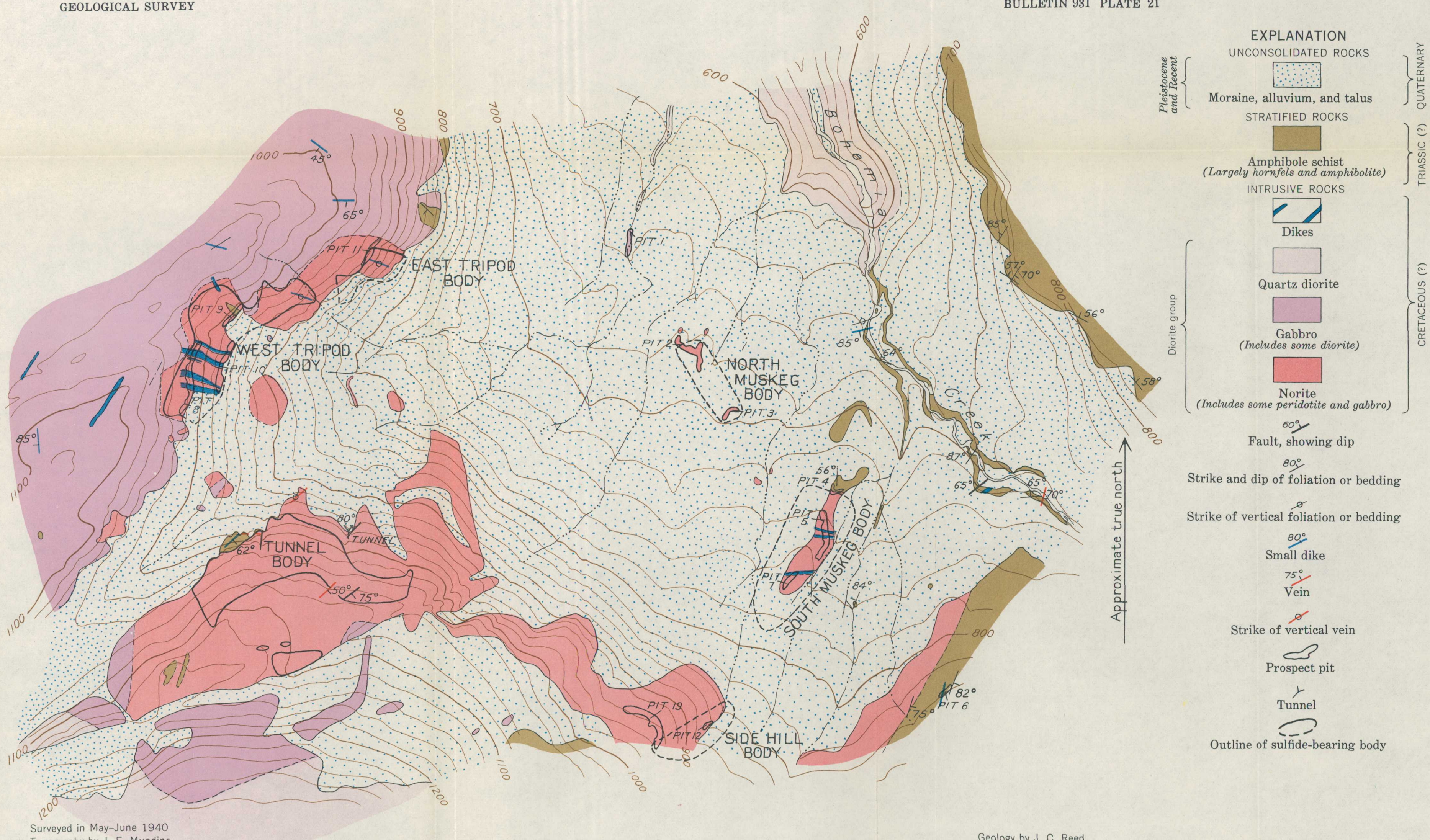

Strike and dip of foliation or bedding Strike of vertical foliation or bedding.

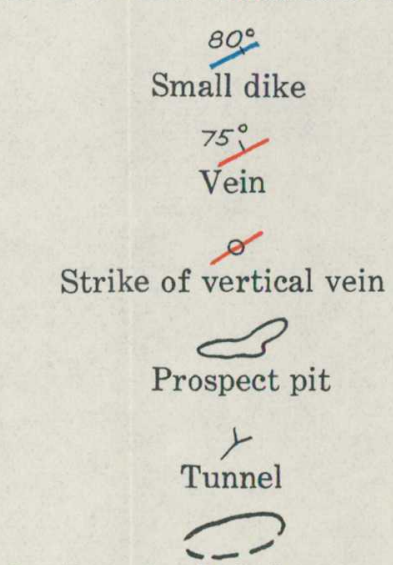

Outline of sulfide-bearing body

GEOLOGIC AND TOPOGRAPHIC MAP OF THE AREA SURROUNDING THE TRIPOD, TUNNEL, SIDE HILL, AND MUSKEG SULFIDE-BEARING BODIES, YAKOBI ISLAND, ALASKA 

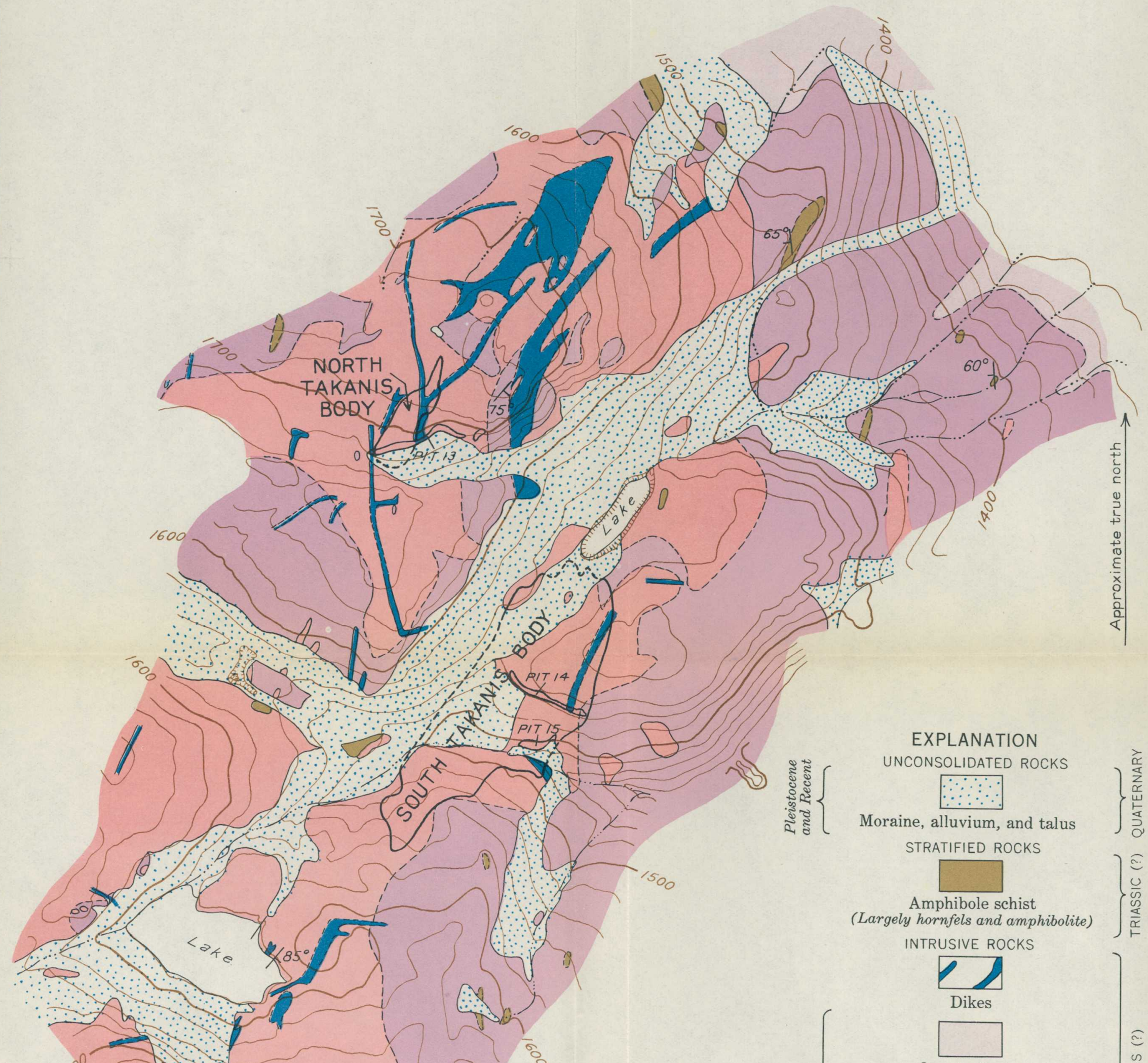

Surveyed in June-July 1940 Topography by J. E. Mundine
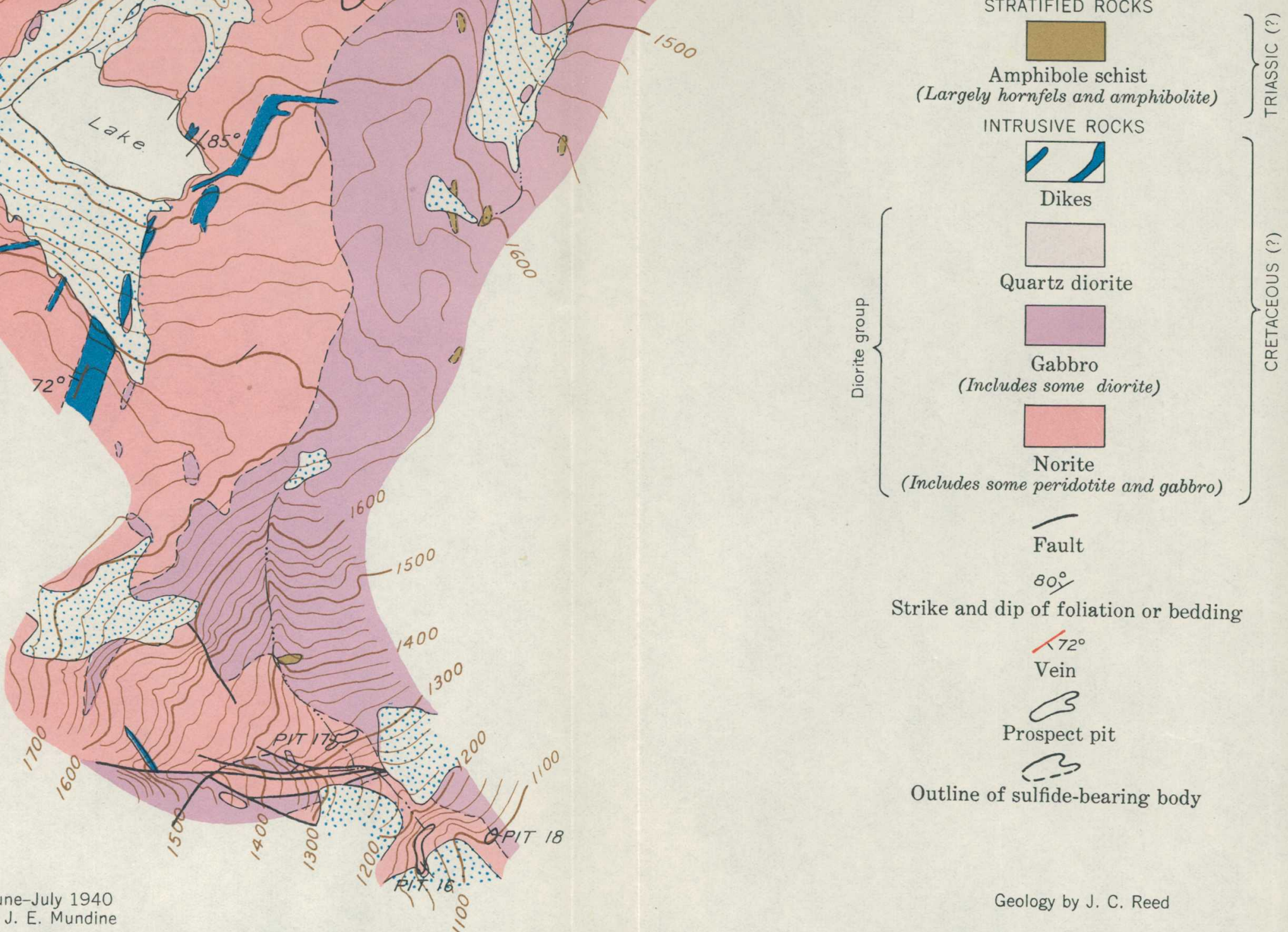

Strike and dip of foliation or bedding

$$
\text { Outline of sulfide-bearing body }
$$

GEOLOGIC AND TOPOGRAPHIC MAP OF THE AREA SURROUNDING THE TAKANIS SULFIDE-BEARING BODIES, YAKOBI ISLAND, ALASKA 
the East Tripod body averaged 0.44 percent of nickel, whereas those of the West Tripod body averaged 0.32 percent of nickel.

Takan1s bodies

The Takanis bodies (see pl. 22) are located at altitudes of 1,500 to 1,700 feet on the ridge which extends northeast from the 2,472-foot peak near the northwest edge of the mapped area. These bodies have been opened by Plts 13, 14, and 15, aggregating 238 feet in the sulfide-bearling bodies, of which 70 feet of Pit 13 is in the North Takan1s body and 168 feet of P1ts 14 and 15 in the South Takanis body. The North body, with a total length of 200 feet, is well exposed and its borders are fairly sharp. Part of the South Takanis body is poorly defined and is to a large extent hidden by talus, alluvium, and moraine, but the body is probably about 550 feet long. The samples from the South Takanis body averaged 0.31 percent of nickel and those from the North Takanis body 0.32 percent.

In and above the east end of P1t 13 several lenses of solid sulfides crop out; the largest is about 3 feet across and 30 feet long. These lenses are localized on prominent jolnts and in sheeted zones in gabbro, and seem to be the result of the accumulation of sulfides from neighboring rock after 1ts solidification. The norlte about 30 feet west of these lenses is apparently barren. Although one of these lenses contains about 3.6 percent of nickel, all of them are small and they contain no significant tonnage. The nlckel-copper ratio of these lenses is very much higher than that of the disseminated bodies.

\section{Unprospected bodies}

$s$

At least four and possibly more unprospected sulfide-bearing bodies crop out in the district. The one that is perhaps the most important is on the steep south slae of the valley of Bohemla Creek, 2,200 feet S. $65^{\circ} \mathrm{E}$. from the southwestern cabin 
(p1. 20). This body, which is several hundred feet across, contains as abundant sulfides as any of the other known bodies, and careful prospecting to define its outline and to determine its grade would be desirable. Like those discussed above, it is near the contact of norite with other rocks, with its longest surface dimension parallel to that contact.

A small but well-exposed sulfide-bearing body was found on a precipitous slope 3,250 feet $\mathrm{S} .82^{\circ} \mathrm{W}$. of the southwestern cabin. It is probably not more than 200 feet across, and 1ts attitude, although not known in detail, appears to be nearly parallel to the slope.

A few outcrops of norite about 500 feet east of the place at which Takanis Creek flows into Takanis Lake carry rather abundant sulfides. Considerable trenching would be necessary to establish the size of this body, because the vegetation is dense and alluvium and moraine are widespread and probably rather thick.

A noteworthy outcrop of sulfide-bearing norite was found 1,200 feet S. $60^{\circ}$ E. of the place at which Takanis Creek flows into Takanis Lake. Talus and moraine are so thick and widespread that the possible extent of the body represented by this and a few other smaller sulfide-bearing outcrops in this vicinity could not be determined.

Indications of other sulfide-bearing bodies were seen in the course of reconnaissance mapping outslde the area shown on plate 20. Many cobbles of sulfide-rich norite, brought into the main valley by tributaries, were found at several places along a stream east of the southern part of the district, especially in the nelghborhood of a large hornfels inclusion to the west of the stream. There are several large bodies of norite in the area west of the 2,472-foot peak near the northwest edge of the area mapped. Part of the outcrop of at least one is highly stained, suggesting a concentration of sulfides. The authors 
belleve that thorough prospecting of the areas in which norite crops out will result in the discovery of more sulfide-bearing bodies.

\section{Tonnage and grade of sulfide-bearing bodies}

Because of the lack of sufficlent direct information, certain basic assumptions were made regarding the size, shape, att1tude, specific gravity, and grade of the bodies in order to calculate their tonnage and grade.

The specific gravity used in computing the tonnage was 3.0 , somewhat lower than that of the sulfide-bearing norite but higher than that of the dikes which cut the sulfide-bearing bodies.

\section{Size, shape, and attitude}

Each body was assumed to extend to a depth below the lowest point on its outcrop equal to one-half its longest surface dimension. Assumption of greater depth without specific evidence is unwarranted because the bodies are believed to be more or less irregular segregations in larger masses of practically barren rock. Sulfide-bearing bodies outcrop throughout a vertical range of more than a thousand feet, but this fact does not indicate that any single body has such vertical extent. Only drillIng or mining operations can prove the true vertical extent of any of the bodies or the relation of the vertical to the surface dimensions.

Each body was assumed to continue vertically downward with the same shape as the surface outcrop. This assumption is undoubtedly in error but was made because of the absence of any specific information.

\section{Grade}

A total of 945 feet of samples was cut from the p1ts and tunnels in the varlous bodies. Because no specific pattern of 
the distribution of nickel values was observed within the bodies or p1ts, other than the very general ones mentioned on page 120, It was assumed that the pits, and hence the samples, are distributed at random in the bodies and that each grade of ore was represented in its tme amount by the samples. The values used for the grade of ore in the well-exposed bodies may well be- too high, because the pits in these bodies were located to some extent in the richer-looking rock whereas the poorly exposed bodles were opened along fortultous outcrops in the muskegs.

\section{Samples}

So far as is known to the writers, their sampling constitutes the first attempt to sample systematicaliy the sulfidebearing bodies of Yakobl Island. In addition to the samples cut in the sulfide-bearing bodies, other samples were taken along lines aggregating 229 feet outside the bodies. The lines along which individual samples were cut range in length from 2 to 40 feet. The weights of the samples range from about 1.5 to about 35 pounds and average a little less than 1 pound per foot. The method by which the samples were analyzed resulted in the determination of all the nickel and copper that is present in sulfide minerals or in any other nickel minerals decomposable by aqua regla.

The samples were more carefully taken than chip samples but are not as reliable as channel samples. Considerable effort was made to include only fresh rock.

The nickel content of the samples ranged from 0.03 to 3.60 percent. The only two samples that contalned more than 1 percent of nickel (samples 20 and 21 ) were taken across a body of solid sulfides 2 to 3 feet thick. Such a small tonnage is represented in this body that it was not included in the estimates made. The nickel content of the norite and gabbro in which 
there is no noticeable concentration of sulfides probably ranges from a trace up to about 0.10 percent.

The table below is divided into two parts on the basis of the different order of accuracy of data for the varlous bodies. In group $A$, both the depth and area components of the tonnage estimate are to some extent hypothetical, whereas in group $B$, the depth factor is hypothetical and the area factor is fairly well-controlled.

Estimated tọnage and grade of sulflde-bearing bodies

\begin{tabular}{|c|c|c|c|c|c|c|}
\hline \multirow{2}{*}{$\begin{array}{c}\text { Solf flde-bearling } \\
\text { bodies }\end{array}$} & \multirow[t]{2}{*}{ Tons } & \multirow{2}{*}{$\begin{array}{l}\text { Asgregate } \\
\text { lengths of } \\
\text { lines along } \\
\text { wh1ch samples } \\
\text { were cut } \\
\text { (feet) }\end{array}$} & \multicolumn{2}{|c|}{$\begin{array}{l}\text { Average grade, } \\
\text { including raste } \\
\text { (percent) }\end{array}$} & \multicolumn{2}{|c|}{$\begin{array}{l}\text { Metal content } \\
\text { (short tons) }\end{array}$} \\
\hline & & & X1chol & Copper & N1ckel & Copper \\
\hline $\begin{array}{l}\text { Group } A: \frac{1}{1} \\
\text { North Musikeg } \\
(P \perp t s 2,3) \ldots .\end{array}$ & 110,000 & 127 & 0.39 & 0.35 & 429 & 385 \\
\hline $\begin{array}{l}\text { South Kuakeg } \\
\text { (P1t \& 4, 5, 7). }\end{array}$ & 766,000 & 176 & .23 & .25 & 1.762 & 1.915 \\
\hline $\begin{array}{l}\text { S1de Hill } \\
(\text { (P1t: 12, 19).. }\end{array}$ & 166,000 & 36 & .26 & .21 & 432 & 349 \\
\hline Totel......... & $1,042,000$ & 399 & .25 & .25 & 2,623 & 2,649 \\
\hline $\begin{array}{l}\left.\text { Oroup } B_{8} 2\right] \\
\text { Tunne1 } \\
\text { (Tunnel)... }\end{array}$ & $1,386,000$ & 106 & .52 & .30 & 7,207 & 4,158 \\
\hline $\begin{array}{l}\text { Test Tripod } \\
\text { (P1ta 8, 9, 10) }\end{array}$ & 908,000 & 232 & $\cdot 32$ & .26 & 2.906 & 2,361 \\
\hline $\begin{array}{l}\text { Fast Tripod } \\
\quad \text { (P1t II) } \ldots \ldots \ldots\end{array}$ & 109,000 & 49 & .44 & .33 & 480 & 360 \\
\hline $\begin{array}{l}\text { North Taloanis } \\
\text { (P1t 13)....... }\end{array}$ & 91,000 & 64 & .32 & .29 & 291 & 264 \\
\hline $\begin{array}{l}\text { South Takan1s } \\
\quad(P 1 \text { t s 14, 15)... }\end{array}$ & $2,317,000$ & 155 & .31 & .25 & 7.183 & 5.793 \\
\hline Total.......... & $4,811,000$ & 606 & .38 & .27 & 18,067 & 12,936 \\
\hline $\begin{array}{l}\text { Total of } \\
\text { groups } \\
\Delta \text { and B..... }\end{array}$ & $5,853,000$ & 945 & .36 & $.27-$ & 20,690 & 15.585 \\
\hline
\end{tabular}


In group A, the estimates of area were made by using all avaliable geologic information, together with the assumptions that certain pits are in the same body, and that, where no information to the contrary was avallable, the widths of the bodles are equal to one-half their lengths. These estimates are belleved to be of the probable correct order of magnitude, but they may be too small, because some bodies, for example the side Hill and the South Muskeg bodles, may be parts of a single much larger body. The areas of the better-exposed bodles of group $B$ are believed to be approximately correct.

The total length of sample lines shown in the table for the North Muskeg body does not correspond to the total length of the sample lines shown for that body on plate 23. This is explained by the fact that sample 22 was omitted from the calculations because its inclusion would have given a disproportionate importance to a small volume of rock.

In obtaining the flgures for the average grades of the bodles in nickel and copper, the various samples were weighted according to the lengths of the lines along which they were cut. Material in the pits that was not sampled because it appeared to be too lean in sulfides to be signiflcant was assumed to contain no nickel or copper. This material was welghted in calculating the average grades according to 1ts proportional exposure in the pits.

\section{Economic considerations.}

The sulfide-bearling bodies of Bohemia Basin and vicinity contain more than 5,800,000 tons of material. This material, as estimated from assays of 61 samples, contains more than 20,000 tons of nickel and more than 15,000 tons of copper. Further prospecting will presumably Increase the 8stimate of the tonnage by (a) the amount of sulfide-bearing material in bodies at present unknown, but which further prospecting will probably dis- 
close, and (b) the amount of material in the bodies now known but unprospected. Further exploration of the incompletely prospected bodies described above, particularly with respect to depth, may decrease but will probably increase the indicated tonnages of those bodles.

The sampling done by the authors is belleved to furnish a safe basis for estimating the order of magnitude of the nickel and copper content of the sulfide-bearing material. Judging from the tenor of material from the unprospected bodies, there is no reason to believe that tonnage added to the present est1mate through further development and exploration would have a metalif content of a different order of magnitude from the material already discovered.

The deposits therefore are appraised on the basis of a minlmum of $5,800,000$ tons of material containing about 0.36 percent of nickel and 0.27 percent of copper. On the basis of long range prices of 35 cents a pound for nickel and 10 cents a pound for copper, the material would contain about $\$ 3.06$ worth of these metals per ton. The mining of the material and the extraction of the metals from 1t present no unusual technical problems.

Rough calculations indicate that the total cost of producing nickel and copper from the Yakob1 Island deposits might approximate the value, at the prices mentioned, of the metals recovered.

Most of the Individual sulfide-bearing bodies are large enough to be mined by some large-scale, low-cost method, and the deposits are favorably situated for low-cost handing of mined material. The bodies contain much material of higher grade than that shown in the table, but any mining operation would almost necessarily involve the mining of most or all the material without selection. Possibly some of the light-colored dike rock could be cobbed out to increase the grade. 
A large mill in the district might concentrate mu-of-mine material, whlch would contain perhaps 4.6 percent by welght of total sulfides, to material that would contain about 80 percent of total sulfides.

The concentrates, worth about $\$ 53$ per ton, would have to be transported by steamer, probably to some port in the Pacific Northwest. The published rate of the Alaska Steamship Co. for transporting similar concentrates from Juneau to Seattle, a comparable distance, is $\$ 4.50$ per ton. This would amount to 26 cents per ton mined for the Yakobi Island material. Operators using their own ships could lower this figure somewhat.

At the present time (1941) no nickel smelter is avallable in the United States, and therefore a new smelting plant would have to be provided. Some possiblilty may exist for selling the concentrates direct to a chemical company, but such an outlet would probably be too small to warrant the large-scale production necessary to keep the mining costs at a reasonable figure..

In addition, a detailed estimate of costs should include such matters as losses of sulfides in mining and milling, insurance, power sources for mining and milling, the large plant investment, cost of marketing, and other factors. Because of these and the other 1tems mentioned above, any attempt to develop the Yakob1 Island deposits would require a great deal of cap1tal.

\section{$\underline{\text { Prospects }}$}

Detalled maps of the tunnel and 19 prospect trenches are shown on a scale of 20 feet to the inch on plate 23. The locations of these workings appear on elther plate 21 or plate 22 .

\section{P1t 1}

P1t 1 was dug to enlarge a sulfide-bearing exposure revealed by a small stream. Bedrock is exposed in the pit over an area 45 feet long and 12 feet in maximum width. The rocks include gabbro, basic pegmatite, norite, and diorite, all mapped as gabbro. This pit was mapped before satisfactory rock subdivi- 
slons were made and the norite and diorite were not different1ated from the gabbro. The basic pegmatite is closely assoclated with the norite and the femic diorite.

Sample 1, which represents the whole outcrop length of the pit, contained so ilttie nickel that none of the rock in this pit is considered to be part of a significant sulfide-bearing body. Sample 2, which was taken along a line 5 feet long and whlch showed 0.47 percent of nlckel, represents the only rock that carries appreclable amounts of sulfides.

\section{P1t 2}

Pit 2 connects several small outcrops and exposes about 120 linear feet of rock. Most of the rock is sulfide-bearing norite but barren gabbro and diorite crop out at the west ond of the p1t. At the southernmost end of the p1t the rock grades from sulfide-rich norite into calcic gabbro and dorite which carry only small amounts of sulfides. Three veins or dikes of quartz and feldspar with accessory biotite crop out in this pit.

\section{P1t 3}

P1t 3 was opened by trenching around a large outcrop in the muskeg and exposes about 35 feet of rock. Calclc gabbro and diorite, similar to that in the south end of P1t 2, crop out prominently in this pit. The distribution of these rock types, as shown on plate 23, illustrates the irregular and lenticular forms common in the norite and gabbro. Some of the mapped boundaries represent sharp contacts but generally there is a gradational zone as much as a foot wide. Sulfides are abundant and evenly disseminated in the gabbro, but are sparse and irregularly distributed in the diorite.

\section{Pit 4}

Pit 4 is a trench which exposes about 30 feet of rock around an outcrop in the muskeg. The pit exposes norite, hornfels, a rock transitional between them, and two pegmatite dikes which cut the other rocks. The hornfels, which is part of a large mass that lies to the east and north, is highly contorted at the north end of the p1t, but nearer the norite $1 t$ is more fractured and grades into it through a zone of breccla, the fragments of which are cemented both by pegmatite and, close to the norite, by dark fine-grained igneous materlal. The norite carries evenly distributed, disseminated sulfides at each end of the part exposed. In the middle of the southern arm of the p1t; the rock is highly altered, and the sample taken there probably contained less sulfides than would be found in fresh rock.

\section{P1t 5}

P1t 5 has been blasted out of the east side of a small bedrock ridge that projects through the moraine. The trench is in rock for a length of 115 feet, of which 13 feet is dike and about 50 feet is calcic gabbro low in sulfides.

Norite, calcic gabbro, hornfels, and dikes of pegmatite and andesite are exposed in the pit. The norite seems to be confined to the southern half of the p1t; the rock north of the more northerly large andesite dike is calcic gabbro containing sparse and irregularly distributed sulfides. The norite contains more abundant sulfides, generally rather evenly disseminated. The norite between the two dikes near the center of the pit is especially rich in sulfides. 
Small irregular inclusions of hornfels, which trend roughly north, are exposed in the north and south parts of the pit.

After the mapping was completed, the pit was extended about 20 feet to the south. The newly exposed rock is all coarsegrained, sulfide-rich norite. Irregular blebs of sulfides as much as an inch across were found in this part of the pit, by far the largest blebs of sulfide seen in the district.

\section{Pit 6}

Pit 6 is on a hiliside near timber line west of Bohemia Creek and is about 38 feet long. The rocks exposed in it include amphibolite (a member of the stratifled rocks), hornfels, injection gneiss, and a quartz diorite dike. The first three are shown as a single unit on plate 23. A little sulfide, apparently pyrite or pyrrhotite, is found in the amphibolite at the east end of the pit but, as no norite crops out, there is no reason to suppose that the sulfides contain appreciable quantities of nickel.

\section{Pit 7}

Pit 7, about 52 feet long, further exposes the east side of the ridge opened by Pit 5. The rocks exposed are calcic gabbro and a diabase dike which has essentially the same mineralogical composition as the gabbro. The calcic gabbro is medium- to coarse-grained and carries a moderate amount of rather evenly disseminated sulfides.

\section{Pit 8}

P1t 8 is blasted out of the steep hill north of the tunnel and is the highest of the group of three pits on that hill. In this pit, 138 feet of rock is exposed. The rocks consist of andesite dikes, norite, and minor calcic gabbro whlch is not differentlated from norite on plate 23.

The norite and calcic gabbro generally contain moderate amounts of disseminated sulfides, but for a few feet at the south end the sulfide content of the rock is much higher, amounting to nearly 40 percent of the rock over areas of several square inches and over somewhat larger areas to about 20 percent. The sulfide content diminishes to the north, and just south of the most southerly dike there was so little present in the rock that no sample was taken. A small fault crosses the southern part of the pit and in that vicinity well-developed foints are conspicuous.

\section{Pit 9}

Pit 9, 64 feet long, is the most northerly of the group of three pits on the hillside north of the tunnel. It exposes norite, hornfels, and several small dikes. The norite is sulfiderich except at the extreme north end of the pit, close to the contact between the norite and the gabbro. The latter contains only very minor quantities of sulfides. The hornfels exposed is part of an inclusion about 50 feet long, which has its long axis about perpendicular to the axis of the pit. The hornfels carries no appreciable sulfides.

\section{Pit 10}

P1t 10 is the lowest of the group of three on the hillside a fow hundred feet north of the tunnel. It is 112 feet long and exposes about 25 feet of dikes and 75 feet of norite. The sam- 
ples indicate two relatively low grade areas in the norite, one In the northern part of the pit and the other fust south of the large dike near the center of the p1t. This pit is believed to be near the east edge of the West Tripod body.

The numerous dikes are characteristically rather irregularly bounded, although the larger ones are persistent enough to be traced up the hill to P1t 8. A small unmapped area of baslc pegmatite lies just south of the most northerly dike.

P1t 11

P1t 11 is several hundred feet northeast of P1t 9 and is the most northerly of the pits on the south side of the through valley that transects the district. About 70 feet of rock is exposed, most of which is norite. At the northern end of the p1t, the norite is relatively rich in feldspar and lean in sulfides. Near this end of the pit there is a small segregation of basic pegmatite. A fault which cuts off a prominent sheeted zone at the south end of the pit dips about $78^{\circ} \mathrm{NW}$. and is marked by a thin quartz vein. That the northwest side moved relatively northeast is suggested by the relation between the more feldspathic and less feldspathic norite. The major movement must have occurred before the emplacement of the dike, which crosses the fault without being offset.

Pit 12

P1t 12 was dug to enlarge a small outcrop in an intermittent stream at the south edge of the area represented on plate 21 . About 33 feet of rock is exposed.

Six kinds of rock are exposed in this small pit: Peridotite, amphibolite (a member of the diorite group), norite, and calcic gabbro, collectively mapped as norite, an andesite dike, and a quartz vein. Near the middle of the pit, in the outcrop area of the amphibolite, the rock is highly altered and now consists largely of ferruginous. clay. There may be a shear zone or a fault in this part of the pit but the rock is too altered to preserve any structure. The sulfide content of all the rocks mapped as norite is relatively high.

\section{P1t 13}

Pit 13 is the highest pit in the Takanis sulfide-bearing bodies. It exposes about 185 feet of rock, of which about 70 feet are in the North Takanis body. The rocks exposed are norite, olivine-rich norite, calcic gabbro, basic pegmatite, and several andesite and quartz andesite dikes. The three firstmentioned rocks were mapped collectively as norite. This pit is notable for two exposures of solid sulfide.

From the west end of the pit to the large dike at the first prominent bend in the pit, the norite is sulfide-bearing, but, from this dike eastward the norite and olivine-rich norite are nearly barren of sulfides almost as far as the middle of the east segment of the pit, where a body of solid sulfide is exposed. The sulfide-bearing norite resembles the barren norite except in the presence of the sulfide minerals.

About 18 feet from the west end of the pit is a body of sulfide-rich norite, which, in areas several inches across, becomes nearly massive sulfide. Dikelike bodies of norlte, seemingly identical with the surrounding rock, locally occupy joints in this vicinity. The rock betweon the joints appears to be sheared, and secondary sulfides, largely chalcopyrite, have been 
deposited in considerable abundance along some of them. The sulfide bodies in and near the east end of the pit have been mentioned on page. 125.

Many of the dikes have extremely irregular boundarles, as if the infected material followed no preexisting fracture during intrusion.

Just west of the large dike near the middle of the pit is a large body of basic pegmatite, characterized by amphibole crystals as much as 4 inches long, which grades into the surrounding norite. This is one of the few masses of basic pegmatite that carry even minor quantities of sulfides.

\section{P1t $14^{\circ}$}

P1t 14 is above and a short distance north of the eastwardflowing stream near the trail leading to the Takanis bodies from Bohemia Basin. About 122 feet of rock is exposed in this p1t. Norite, altered diorite which is mapped as gabbro, and dike rock, at least some of which is quartz diorite, are found in Pit 14. The norite exposed in the northwest part of the pit is rich in sulfides, but that in the southeast part is nearly barren. The rock mapped as gabbro carries extremely minor amounts of sulfides. The dikes in the central part of the pit and the one near the southeast end are complexly zoned.

A little basic pegmatite, unusual in that it is separated from the enclosing norite by sharp contacts, crops out in the southeast end of the pit.

\section{P1t 15}

Pit 15 is a short distance below Pit 14 and just above the creek near the trail that leads to the Takanis bodies from Bohemia Basin. About 53 feet of rock consisting mainly of norite but including a little pegmatite is exposed. The east end of the pit is rich in sulfides, but the sulfide content of the norite decreases westward and is relatively low at the west end.

\section{P1t 16}

P1t 16, at the south end of the area represented by plate 22, is in a small stream that drains into the head of the lake at the head of Takanis Creek. It exposes about 65 feet of rock. Except for one small andesite dike, all the rock is norite, but sulfides are so sparse that this pit was not sampled.

About 25 feet above this pit is a fault that strikes No $68^{\circ}$ E. and dips $68^{\circ} \mathrm{NW}$., and about 18 feet above this fault is another, parallel fault. Both fault fissures contain about 8 inches of antigorite. Slickensides which are nearly horlzontal Indicate that the latest movement at least was lateral.

\section{P1t 17}

P1t 17 is the highest of the three pits along the small stream at the southern end of the area represented by plate 22. About 63 feet of rock is exposed, including norite, calcic gabbro, basic pegmatite, andesite dikes, and hornfels. The norite occupies the western two-thirds of the p1t, but it carries so little sulfide that the pit was not sampled. The norite contains tabular, sharply bounded masses of basic pegmatite. 
The eastern third of this pit is a complex of hornfels, norite, and calcic gabbro. The hornfels is baked, contorted, and recrystallized. It is characterized by quarter-inch crystals of amphibole, which are belleved from their shape to be secondary after pyroxene. The calcic gabbro surrounds inclusions of horn-. fels and is rich in feldspar. Two small dikes, probably andesite, are exposed in the pit. They are tabular and are parallel to the joints of the major joint system.

A low-angle fault runs the length of the pit and offsets all features except some of the jolnts and one of the dikes. This fault dips $20^{\circ}$ to the north, and the upper side moved westward.

\section{P1t 18}

Pit 18 is a short distance downstream from P1t 16 and is 18 feet long. It exposes norite and part of an andesite dike. The norite carries a little sulfide but was not sampled.

\section{Pit 19}

P1t 19 is about 100 feet west of Pit 12; on the south edge of the area represented on plate 2l. It exposes about 143 feet of norite, calcic gabbro, and basic pegmatite on a slope covered with talus.

About 36 feet of sulfide-bearing norite crops out in the south end of the pit, but the rest of the pit is in light calcic gabbro which contains very minor quantities of sulfides. Small blebs and segregations of basic pegmatite are scattered apparently at random through the main body of gabbro, into which they grade. In the west part of the east half of the pit is a tabular body of fine-grained gabbro somewhat more basic than the surrounding gabbro.

\section{Tunnel}

A tunnel about 166 feet long has been driven into the hillside 1,300 feet $\mathrm{S}$. $18^{\circ} \mathrm{W}$. of the larger cabin in Bohemia Basin. Norite, quartz pegmatite, and quartzitic schist are exposed, but only the first two were mapped. Norite is exposed along the whole length of the tunnel and is sulfide-bearing except for the interval between 15 and 53 feet from the portal. The sulfide seems to be rather evenly distributed in blebs up to a third of an inch across. Quartz pegmatite veins are exposed at two places but are only a few inches thick.

A specimen of quartzitic schist was taken from the west side of the face of the tunnel. It probably is from a small inclusion in the norite.

\section{Other prospect pits}

A group of four pits have been excavated about 2,400 feet N. $62^{\circ}$ W. of the mouth of Bohemia Creek. Much of the rock is extremely coarse-grained amphibolite containing minor amounts of pyrite, chalcopyrite, and pyrrhotite. The amphibolite ranges from a rock made up of massive, interlocking amphibole crystals $\frac{1}{2}$ to 2 inches long to fine-grained, gnelssic amphibolite containing as much as 50 percent clinozolsite, the latter mineral apparently the result of late magmatic alteration. The sulfides are concentrated on cleavage surfaces in the amphibole and as smears on joint planes and in cracks. A quantitative analysis of some of the richest sulfide-bearing rock from this area showed 0.012 percent of nickel. 
A pit on the west bank of a large creek, 7,300 feet N. $58^{\circ} \mathrm{W}$. of the mouth of Bohemia Creek, exposes a zone of thoroughly crushed, sheared, and silicified rock in which the major constituents are now quartz and epidote. This rock probably developed from amphibolite schist. Abundant pyrite has been deposited in this zone, but a qualitative analysis of some of the rock that appeared to be richest in sulfides showed no nickel.

0 
The use of the subjoined mailing label to return this report will be official business, and no postage stamps will be required

UNITED STATES

DEPARTMENT OF THE INTERIOR

GEOLOGICAL SURVEY

OFFICIAL BUSINESS

This label can be used only for returning official publications. The address must not be changed.
PENALTY FOR PRIVATE USE TO AVOID PAYMENT OF POSTAGE, $\$ 300$

\section{GEOLOGICAL SURVEY,}

